\title{
Enzymatically and/or thermally treated Macroalgae biomass as feedstock for fermentative $\mathrm{H}_{2}$ production
}

\author{
Emelin Leandro Rodrigues ${ }^{1}$, Bruna Constante Fonseca ${ }^{1}$, \\ Valeria Cress Gelli ${ }^{2}$, Sibeli Carli ${ }^{1}$, Luana Parras Meleiro ${ }^{1}$, \\ Rosa Prazeres Melo Furriel ${ }^{1}$, Valeria Reginatto ${ }^{1}$
}

\footnotetext{
${ }^{1}$ Departamento de Química, Faculdade de Filosofia Ciências e Letras de Ribeirão Preto - FFCLRP- Universidade de São Paulo - USP, Av. Bandeirantes, 3900 - CEP 14040-030, Ribeirão Preto, São Paulo, Brasil.

${ }^{2}$ Departamento de Pesca -Núcleo de pesquisa e desenvolvimento do Litoral Norte - Agência Paulista de Pesquisa Agropecuária, Secretaria de Agricultura e Abastecimento do Estado de São Paulo, Ubatuba, São Paulo, Brasil.

e-mail: valeriars@ffclrp.usp.br
}

\begin{abstract}
Due to its high carbohydrate content, algae biomass can be employed as feedstock to produce hydrogen (H2) by fermentation. However, to make the carbohydrates entrapped within the cell wall more bioavailable, algae biomass must be treated before fermentation. We submitted Kappaphyccus alvarezzi macroalgae biomass to autoclave (at $120{ }^{\circ} \mathrm{C}$ and 1 atm for $6 \mathrm{~h}$ ) treatment and/or enzymatic (Celluclast ${ }^{\circledR}$ and/or a recombinant $\beta$ glucosidase) hydrolysis, to break down complex carbohydrates into available sugars that were used to produce $\mathrm{H} 2$ by fermentation. Macroalgae biomass treated with Celluclast ${ }^{\circledR}+\beta$-glucosidase and with combined thermal treatment and enzymatic hydrolysis reached very similar TRS productivities, 0.24 and $0.22 \mathrm{~g}$ of TRS/L.h, respectively. The enzymatically treated biomass was employed as feedstock to produce $\mathrm{H} 2$ by Clostridium beijerinckii $\mathrm{Br} 21$, which afforded high yield: $21.3 \mathrm{mmol}$ of $\mathrm{H} 2 / \mathrm{g}$ of dry algae biomass. Hence, treatment with Celluclast ${ }^{\circledR}$ and recombinant $\beta$-glucosidase provided macroalgae biomass for enhanced bioconversion to $\mathrm{H} 2$ by $\mathrm{C}$. beijerinckii $\mathrm{Br} 21$.
\end{abstract}

Keywords: Kappaphyccus alvarezzi, Clostridium beijerinckii, Biohydrogen, Cellulase, $\beta$-glucosidase.

\section{INTRODUCTION}

Nowadays, one of the most important environmental issues is to replace finite, polluting fossil fuels with sustainable fuels [1,2]. In this context, hydrogen $\left(\mathrm{H}_{2}\right)$ is an alternative fuel to the traditional ones: $\mathrm{H}_{2}$ combustion produces water only, and this fuel has three times higher energy potential than gasoline $\left(142 \mathrm{~kJ}^{-1}{ }^{-1}\right)$ $[1,3,4,5]$. However, physical-chemical methods, which also depend on fossil fuels or require a large amount of energy, are mainly employed to obtain $\mathrm{H}_{2}$ [4]. Alternatively, biological routes, such as fermentation, can be used to obtain $\mathrm{H}_{2}[1,3]$. The fermentative route is promising in terms of cost and sustainability because it employs renewable raw materials, including carbohydrate-rich biomasses, at ambient temperature and pressure $[6,7]$.

Due to its high carbohydrate content, macroalgae biomass is a suitable carbohydrate source for biotechnological processes, like fermentative $\mathrm{H}_{2}$ production [7,8]. Compared to higher plant biomass, algae offer a number of potential advantages: 1) they convert sunlight to biochemical energy more efficiently than terrestrial plants; 2) they grow on vast tracts of sea by action of sunlight only, without the need for fertilizers; 3) their production does not depend on arable land availability, so their cultivation does not compete with food production; 4) they consume $\mathrm{CO}_{2}$, thereby helping to reduce greenhouse gas emissions; and 5) they do not contain lignin, which simplifies biomass saccharification processes for further use in fermentation [6-16].

Most carbohydrates are entrapped within the algae cell wall, so $\mathrm{H}_{2}$ production by algae biomass fermentation requires cell wall disruption. Different methods - chemical, physical, biological, or a combination of them - can be applied to algae biomass to make oligo- and monosaccharides available [10, 12, 17]. Some methods can decompose sugars and generate fermentation inhibitors, like 5-hydroxymethylfurfural (HMF) and organic acids [18].

Thermal methods are cost-effective because they do not require that any chemicals other than water be added or recovered. For example, hydrothermal hydrolysis uses water at high temperatures (above $150^{\circ} \mathrm{C}$ ) and controlled atmosphere to break polysaccharides into smaller molecules. In the specific case of algae bio- 
mass, which does not contain lignin, the hydrothermal method is very promising $[12,13]$. Compared to other methods, such as acid treatment, hydrothermal hydrolysis provides high sugar recovery and produces inhibitors at low concentration [13, 18]. However, hydrothermal biomass treatment demands special reactors that can support high temperature and pressure $[12,13]$. For this reason, here we employed a modified hydrothermal method based on autoclave, an easily available lab instrument, to treat algae biomass.

In this study, we use the red seaweed Kappaphyccus alvarezzi as macroalgae biomass because of its high carbohydrate content (about 50\%). The carbohydrates present in this algae consist of heterogeneous polysaccharides called carrageenans, which are composed mainly of D-galactose and 3,6-anhydro-Dgalactose sulfated at the $\beta-1,4-$ and $\alpha-1,3$ bonds [19]. We applied autoclave treatment and/or enzymatic hydrolysis to the $K$. alvarezzi biomass and determined sugar and inhibitor concentrations in the hydrolysates aiming at their further use in $\mathrm{H}_{2}$ production via fermentation.

\section{MATERIALS AND METHODS}

\subsection{Macroalgae biomass}

The $K$. alvarezzi biomass, grown in the Atlantic, was provided by the Fisheries Institute, Ubatuba, São Paulo (SP) (GPS coordinates $23^{\circ} 27^{\prime} 5,8^{\prime \prime} \mathrm{S} ; 4^{\circ} 02^{\prime} 49,3^{\prime \prime} \mathrm{W}$ ), after natural air-drying. Approximately $25 \mathrm{~g}$ of the dried seaweed biomass was washed five times with $1 \mathrm{~L}$ of deionized water to remove impurities. The sample was dried in an air circulation oven at $50{ }^{\circ} \mathrm{C}$ for $24 \mathrm{~h}$, milled (SL31, Solab - Brazil), and screened through a 45mesh sieve $(0.355 \mathrm{~mm})$ (Bertel, Brazil) to standardize the biomass for the treatments.

\subsection{Algae biomass treatments}

Autoclave treatment and enzymatic hydrolysis were carried out alone or in combination. The biomass was treated in $125-\mathrm{mL}$ erlenmeyers containing $0.5 \mathrm{~g}$ of dry algae biomass and $50 \mathrm{~mL}$ of deionized water or buffer (in the case of enzymatic hydrolysis), to give $10 \mathrm{~g} / \mathrm{L}$ algae suspensions. All the experiments were conducted in triplicate, with a control. The total reducing sugars (TRS) concentration of the control was subtracted from the TRS concentration of the sample.

\section{Autoclave treatment}

Autoclave treatment was accomplished in a bench vertical autoclave (Phoenix Luferco) at $121{ }^{\circ} \mathrm{C}$ and $1 \mathrm{~atm}$. After treatment, the suspension was filtered through a $0.45-\mu \mathrm{m}$ porous acetate-cellulose membrane to determine the TRS concentration and the concentration of potential fermentation inhibitors (acetic acid and HMF). As for the control, an algae suspension was left at ambient temperature for the same duration of the thermal treatment.

\section{Enzymatic hydrolysis}

Enzymatic hydrolysis was carried out with $0.5 \mathrm{~g}$ of $K$. Alvarezzi biomass in $50 \mathrm{~mL}$ of $0.1 \mathrm{moL} / \mathrm{L}$ citrate buffer, $\mathrm{pH}$ 4.8. Next, 60 enzymatic units per gram of dry algae biomass (U/g) was added. The following enzymes were employed: Celluclast ${ }^{\circledR}$ (provided by Novozymes, São José dos Pinhais, Brazil) and a recombinant $\beta$ glucosidase (Bglhi) from Humicola insolens [20]. The enzymes were added alone or together after the temperature had stabilized at $50{ }^{\circ} \mathrm{C}$, which was maintained during the assay. In the end, $1-\mathrm{mL}$ samples were collected to quantify the TRS and HMF concentrations. As for the control, algae biomass was suspended in buffer and incubated at the same temperature used during enzymatic hydrolysis but without addition of enzymes.

\section{Combined treatment}

The combined treatment consisted in autoclave treatment followed by enzymatic hydrolysis. The erlenmeyer containing the algae suspension $(10 \mathrm{~g} / \mathrm{L})$ in deionized water was autoclaved at $121{ }^{\circ} \mathrm{C}$ and 1 atm for $6 \mathrm{~h}$. After that, a sample of the treated suspension was collected and filtered, and its TRS content was measured. The algae (in suspension) treated by autoclave was added with $30 \mathrm{U}$ of each enzyme (Celluclast ${ }^{\circledR}$ and recombinant $\beta$-glucosidase) per gram of algae, and the algae suspension was kept at $50{ }^{\circ} \mathrm{C}$. Finally, 1 -mL samples 
were taken to determine TRS and inhibitors. The control was not thermally treated in the first step, but it was incubated at $50{ }^{\circ} \mathrm{C}$ without enzymes in the second step.

\subsection{Hydrolysis yield}

To calculate the amount of sugar released after the autoclave, enzymatic, and combined treatments, the $K$. alvarezzi total carbohydrate concentration of $51.33 \%$ measured by DALBELO [21] was considered, as described in Equation 1.

$$
Y_{T R S}=\frac{[T R S] * V}{M A * \% C} * 100 \quad \text { Equation } 1
$$

$\mathrm{Y}_{\mathrm{TRS}}=$ hydrolysis yield as percent of TRS $(\%)$.

$[$ TRS $]=$ TRS concentration in the treated suspension $(\mathrm{g} / \mathrm{L})$.

$\mathrm{V}=$ algae suspension volume $(0.05 \mathrm{~L})$.

$\mathrm{MA}=$ algae mass in the assay $(\mathrm{g})$.

$\% \mathrm{C}=0.513$ percent of total carbohydrate content in the algae biomass.

\subsection{Recombinant $\beta$-glucosidase expression and purification for enzymatic hydrolysis}

Bglhi was overexpressed in Escherichia coli BL21 (DE3) after transformation with the previously constructed plasmid pET28_bglhi containing the Bglhi coding sequences [20]. The cells were grown in HDM medium $\left(25 \mathrm{~g} / \mathrm{L}\right.$ yeast extract, $15 \mathrm{~g} / \mathrm{L}$ tryptone, and $\left.10 \mathrm{mmol} / \mathrm{L} \mathrm{MgSO}_{4}\right)$ supplemented with specific antibiotics at 37 ${ }^{\circ} \mathrm{C}$ to an $\mathrm{OD}_{600}$ of approximately 0.6. Protein expression was induced by addition of isopropyl- $\beta$-D-1thiogalactopyranoside to the culture medium at a final concentration of $1 \mathrm{mmol} / \mathrm{L}$. After 5 -h induction at 37 ${ }^{\circ} \mathrm{C}$, the cells were collected by centrifugation at $5000 \mathrm{x} g$ and $4{ }^{\circ} \mathrm{C}$ for $20 \mathrm{~min}$. The pellet was re-suspended in lysis buffer $(50 \mathrm{mmol} / \mathrm{L}$ HEPES buffer, $\mathrm{pH} 8.0$, containing $500 \mathrm{mmol} / \mathrm{L} \mathrm{NaCl}$ and $1 \%$ Triton X-100 (v/v)) and disrupted by sonication. Cell debris was removed by centrifugation, and the recombinant protein was purified from the supernatant by nickel affinity chromatography (HisLink ${ }^{\mathrm{TM}}$, Promega), according to the manufacturer's instructions.

\subsection{Cellulase and $\beta$-glucosidase enzymatic activity assays}

Celluclast ${ }^{\circledR}$ activity was determined by using filter paper as substrate. After $60 \mathrm{~min}$, the DNS method was used to quantify TRS release, as described in GHOOSE [22].

The $\beta$-glucosidase activity was determined by using the synthetic substrate $p$-nitrophenyl- $\beta$-Dglucopyranoside ( $p$ NP-Glc) at $2 \mathrm{mmol} / \mathrm{L}$. The yellow $p$-nitrophenol product was quantified at $410 \mathrm{~nm}$, according to the methodology described by SOUZA et al. [20]. In both cases, one enzyme unit (U) was defined as the amount of enzyme that released $1 \mu \mathrm{mol}$ of product per min.

\subsection{Fermentative $\mathrm{H}_{2}$ production assay}

Fermentation assays were conducted by using the filtered algae suspension obtained by enzymatic hydrolysis, which was the one with the highest TRS productivity. The $\mathrm{H}_{2}$-producing $C$. beijerinckii $\mathrm{Br} 21$, which can produce $\mathrm{H}_{2}$ from D-galactose, the main algae biomass monosaccharide, was employed. This microorganism was cultivated as described by FONSECA et al. [23]. The culture was prepared $24 \mathrm{~h}$ before the inoculum was cultivated, and the culture with 0.1 optical density at $600 \mathrm{~nm}$ was added to the hydrolysate.

The fermentation assays were performed in $50-\mathrm{mL}$ vials containing $14 \mathrm{~mL}$ of the algae sample in $0.22-\mu \mathrm{m}$ membrane and $1 \mathrm{~mL}$ of inoculum, added to previously sterilized vials. Macro- and micronutrients were added to the hydrolysate, as described by FONSECA et al. [23]. After inoculation, argon gas was bubbled into the vials, which were sealed with rubber stoppers or metal stoppers. After $72 \mathrm{~h}$ at $35^{\circ} \mathrm{C}$, the gas from the vial headspace was analyzed by gas chromatography. The assay was accomplished in duplicate. Culture medium samples were taken at the beginning and at the end of the fermentation assays to measure ART and $\mathrm{pH}$.

The volume of produced $\mathrm{H}_{2}$ was calculated by considering the headspace volume and the gas composition according to the ideal gas equation, $(\mathrm{P} . \mathrm{V}=\mathrm{n} . \mathrm{R} . \mathrm{T})$, where $\mathrm{P}$ is pressure $(1 \mathrm{~atm}), \mathrm{V}$ is the $\mathrm{H}_{2}$ volume, $\mathrm{n}$ 
is the number of moles of $\mathrm{H}_{2}, \mathrm{R}$ is the universal constant of an ideal gas ( $\left.0.082 \mathrm{~atm} \mathrm{~L} / \mathrm{K} \cdot \mathrm{mol}\right)$, and $\mathrm{T}$ is the absolute temperature $(\mathrm{K})$, as described by FONSECA et al. [23].

The $\mathrm{H}_{2}$ yield from the hydrolysate $\left(\mathrm{Y}_{\mathrm{H} 2 / \mathrm{S}}\right)$ was determined according to Equation 2.

$Y \frac{H_{2}}{S}=\frac{\Delta H_{2}}{\Delta S} \quad$ Equation 2

$\mathrm{Y}_{\mathrm{H} 2 / \mathrm{S}}=\mathrm{H}_{2}$ yield calculated from the sample ART concentration.

$\Delta \mathrm{H}_{2}=$ difference between $\mathrm{H}_{2}$ concentration, in moles (considering $\mathrm{H}_{2}$ molecular weight of $2 \mathrm{~g} / \mathrm{mol}$ ), at the beginning and at the end of the fermentative assay.

$\Delta \mathrm{S}=$ difference between ART concentration in moles (considering sugar as glucose molecular weight, 180 $\mathrm{g} / \mathrm{mol}$ ) at the beginning and at the end of the fermentative assay.

The $\mathrm{H}_{2}$ yield as a function of the initial algal biomass (Y) was also calculated as the ratio between the number of moles of produced $\mathrm{H}_{2}$ and the initial dry algae biomass.

\subsection{Analytical Methods}

Samples of the algae suspensions collected after autoclave treatment and enzymatic hydrolysis were filtered through $0.45-\mu \mathrm{m}$ acetate cellulose membrane before analytical determinations were carried out. The TRS concentration was obtained by using the 3,5-dinitrosalicyclic acid (DNS) method, as described by Miller [24].

The length of the carbohydrate products formed after autoclave treatment and after enzymatic hydrolysis with the two enzymes was analyzed by thin layer chromatography (TLC). Aliquots of the filtered samples were treated with $10 \%$ trichloroacetic acid $(\mathrm{w} / \mathrm{v})$, to precipitate proteins and long-chain carbohydrates. The samples were kept at room temperature for $30 \mathrm{~min}$ and centrifuged at 10,000 $\mathrm{x} g$ for $15 \mathrm{~min}$. The supernatants $(10 \mu \mathrm{L})$ were analyzed by TLC on silica gel G-60 plates $(10 \times 15 \mathrm{~cm}$, DC-Alufolien Kiesel gel 60, Merck, Darmstadt, Germany), as described by CARLI et al. [25].

HMF in the hydrolysates was quantified by high performance liquid chromatography (HPLC). To this end, $500 \mu \mathrm{L}$ of the sample was injected into a high performance liquid chromatograph (Shimadzu, Japan) under the following conditions: ion exclusion column Aminex HPX-87H 300 x 7.8 mm) from Bio Rad, mobile phase $=5 \mathrm{mM}$ sulfuric acid in milli Q water, flow $=0.6 \mathrm{~mL} / \mathrm{min}$ (Pressure $\left.=68 \mathrm{Kgf} / \mathrm{cm}^{2}\right)$, detector operating at $190 \mathrm{~nm}, 205 \mathrm{~nm}$, and $276 \mathrm{~nm}=$ diode array (model SPDM10A-VP), and Refractive Index (Model: RID-10A).

Following the procedures described in a previous work by our group [23], the composition of the gas originating from the fermentative assays was identified by gas chromatography (GC). A $100-\mu \mathrm{L}$ aliquot collected from the bioreactor headspace was injected into the chromatograph GC 2014 Shimadzu (Japan) chromatograph equipped with a thermal conductivity detector (TCD) with a gas-tight syringe. The chromatographic column $(2 \mathrm{~m} \mathrm{x} 4.7 \mathrm{~mm})$ consisted of 5 -Å molecular sieves. Argon at a flow rate of $30 \mathrm{~mL} / \mathrm{min}$ was employed as the carrier gas.

\subsection{Statistical analysis}

To compare the kinetic parameters obtained in treatment tests, analysis of variance (ANOVA) and Tukey test at a 5\% significance level were accomplished by using the software Statistic 7.0.

\section{RESULTS AND DISCUSSION}

\subsection{Macroalgae treatment}

Figure 1 presents the algae suspension TRS concentration after autoclave treatment $(0-6 \mathrm{~h})$. The TRS concentration did not increase significantly in the first two hours of treatment. Thereafter, the TRS concentration increased gradually until it reached a maximum of $0.95 \mathrm{~g} / \mathrm{L}$ after $6 \mathrm{~h}$ of autoclave treatment at $120^{\circ} \mathrm{C}$ and 1 atm. This concentration corresponded to a hydrolysis yield $\left(\mathrm{Y}_{\mathrm{TRS}}\right)$ of ca. $18.5 \%$ (Figure 1) and was similar to 
the yield obtained by BARREIRO et al. [26], who recovered 19.5, 38, and $21.9 \%$ of total organic carbon (TOC) in hydrolysates after hydrothermal treatment of the macroalgae Fucus vesiculosus, Laminaria saccharina, and Alaria esculenta, respectively. However, the aforementioned authors employed a temperature of $350{ }^{\circ} \mathrm{C}$ for only 15 min of hydrothermal treatment [26].

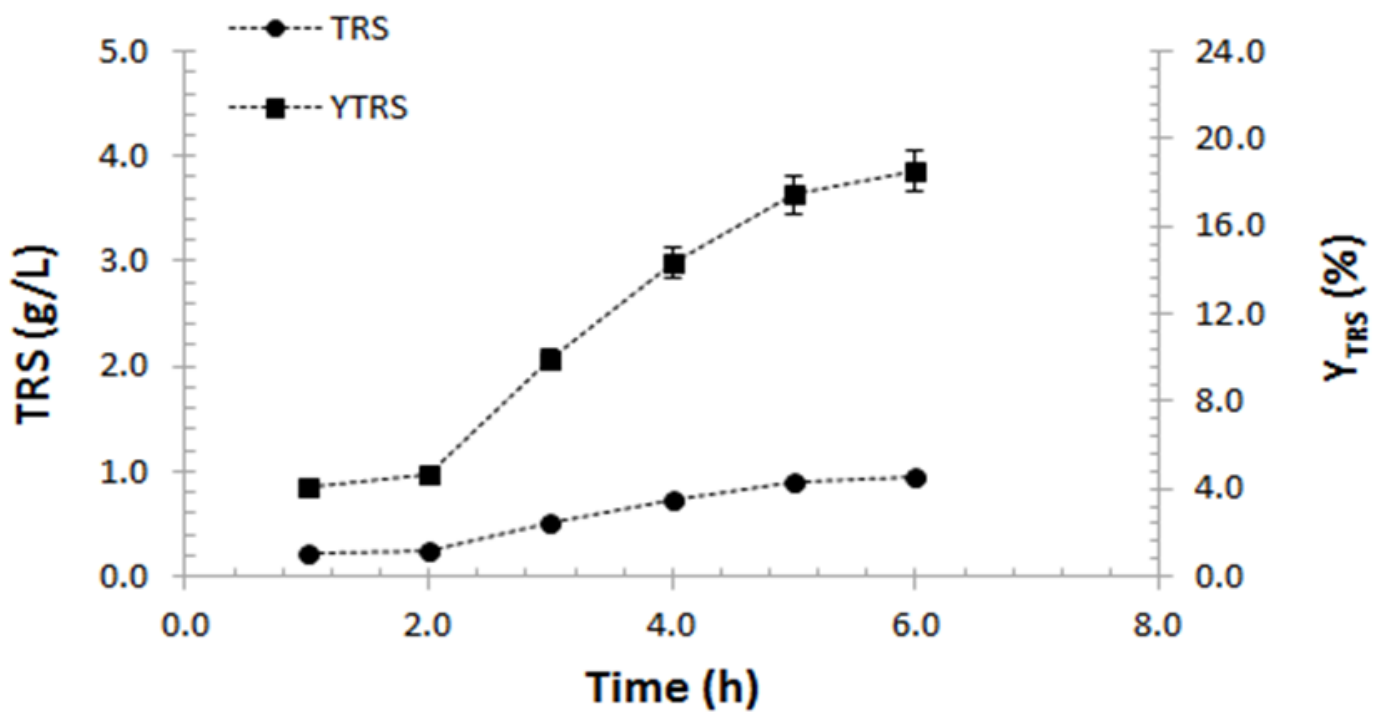

Figure 1: TRS concentration during the autoclave treatment at $120^{\circ} \mathrm{C}$. The percent TRS yield was calculated by considering $51.3 \%$ total carbohydrate content in $K$. alvarezii.

Figures $2 \mathrm{a}, 2 \mathrm{~b}$, and $2 \mathrm{c}$ represent the TRS concentration during enzymatic hydrolysis of algae biomass by Celluclast ${ }^{\circledR}$ alone, recombinant $\beta$-glucosidase alone, and a mixture of both enzymes (Celluclast ${ }^{\circledR}+\beta$ glucosidase), respectively. Celluclast ${ }^{\circledR}$ alone afforded hydrolysis yield of 23.4 and $31.2 \%$ after 6 and 12 h, respectively (Figure 2a). Macroalgae cell wall contains cellulose as well as carrageenan. Both polysaccharides bear $\beta$-1,4-glucosidic bonds, so endocellulases such as Celluclast ${ }^{\circledR}$ can potentially depolymerize them. Endoglucanases act within the polysaccharide chains, to release oligosaccharides with reducing ends. These oligosaccharides can be detected by the DNS method used to quantify TRS herein and, depending on their molecular mass, they can be further fermented [24].

On the other hand, $\beta$-glucosidases are more active on small oligosaccharides, mainly the glucose disaccharide linked by $\beta-1,4$ bonds; i.e., cellobiose [27]. The yield of macroalgae hydrolysis by $\beta$-glucosidase alone was very low, ca. $4 \%$, even after 6 h (Figure $2 \mathrm{~b}$ ). Nevertheless, we expected that $\beta$-glucosidase could complement the Celluclast ${ }^{\circledR}$ action by hydrolyzing the released oligosaccharides. In fact, $\beta$-glucosidase together with cellulase increased the TRS concentration in the hydrolysate (Figure 2c). The hydrolysis yield obtained with Celluclast $\AA$ alone and with the mixture Celluclast $\AA+\beta$-glucosidase was 31 (after 12 h) and $37 \%$ (after 8 h), respectively. Brown seaweed Ecklonia radiata saccharification by Celluclast ${ }^{\circledR}$ together with other hydrolytic enzymes also improved the total sugar yield slightly as compared to Celluclast ${ }^{\circledR}$ alone [28]. According to a literature review [8] of carrageenan enzymatic hydrolysis, only endotype carrageenases that act on carrageenan $\beta$-1,4-linkages (to produce oligosaccharides and carrabiose) have been reported. For complete carrageenan enzymatic monomerization, currently unavailable enzymes like exotype carrageenases and carrabiose hydrolases must be identified [8]. On the basis of our results, even though Celluclast® is not specific for carrageenan, it is a potential biocatalyst for carrageenan-containing macroalgae biomass, such as the red $K$. alvarezzi macroalgae. In addition, recombinant $\beta$-glucosidase increases TRS concentration in the algae hydrolysate even more. Hence, the enzyme mixture employed here is a good alternative for algae hydrolysis. 

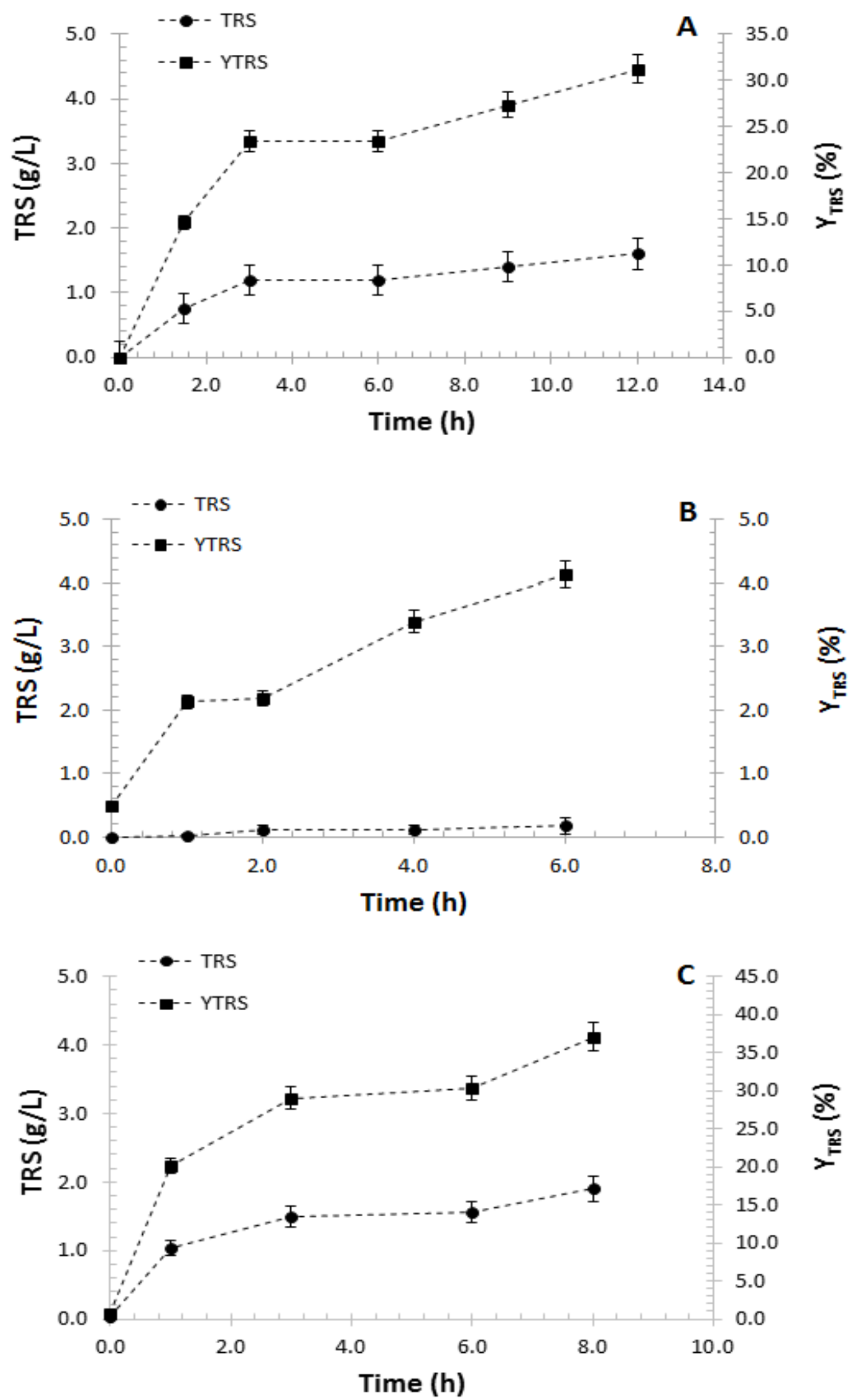

Figure 2: TRS concentration and hydrolysis yield after enzymatic treatments. A) Celluclast $\left.{ }^{\circledR}, \mathrm{B}\right) \beta$-glucosidase, and C) Celluclast ${ }^{\circledR}+\beta$-glucosidase. All the treatments used total enzyme concentration of $60 \mathrm{U} / \mathrm{g}$ of algae biomass. The percent TRS yield was calculated by considering that $K$. alvarezii presented $51.3 \%$ of total carbohydrate content. 
Finally, we combined autoclave treatment $(6 \mathrm{~h})$ and enzymatic hydrolysis (Celluclast ${ }^{\circledR}+\beta-$ glucosidase) (Figure 3). The TRS concentration in the hydrolysate at the beginning of the assay was ca. $1 \mathrm{~g} / \mathrm{L}$ (time zero), which was the TRS concentration in the hydrolysate after $6 \mathrm{~h}$ of thermal treatment in the autoclave. Enzymatic hydrolysis with Celluclast ${ }^{\circledR}$ and $\beta$-glucosidase increased the TRS concentration in the thermal hydrolysate from 1 to $3.2 \mathrm{~g} / \mathrm{L}$, which corresponded to a total saccharification yield of $61.5 \%$. This represented an increase of over $100 \%$ in the yield obtained after thermal hydrolysis yield alone (Figure 1) and an increase of $24 \%$ in the yield obtained after enzymatic hydrolysis with both enzymes, which was $37 \%$ (Figure 2c). LEE, et al. [29] recovered $44.8 \%$ of D-galactose and 3,6-anhydro L-galactose, the main red macroalgae cell wall monosaccharides, when they used acid-base buffer $(20 \mathrm{mM}$ Tris- $\mathrm{HCl})$ and agar hydrothermal pretreatment at $170{ }^{\circ} \mathrm{C}$, for $10 \mathrm{~min}$, followed by enzymatic hydrolysis. Our saccharification yields were higher than the values obtained by LEE et al. [29] even though they used specific Saccharophagus degradans 2-40T agarolytic recombinant enzymes.

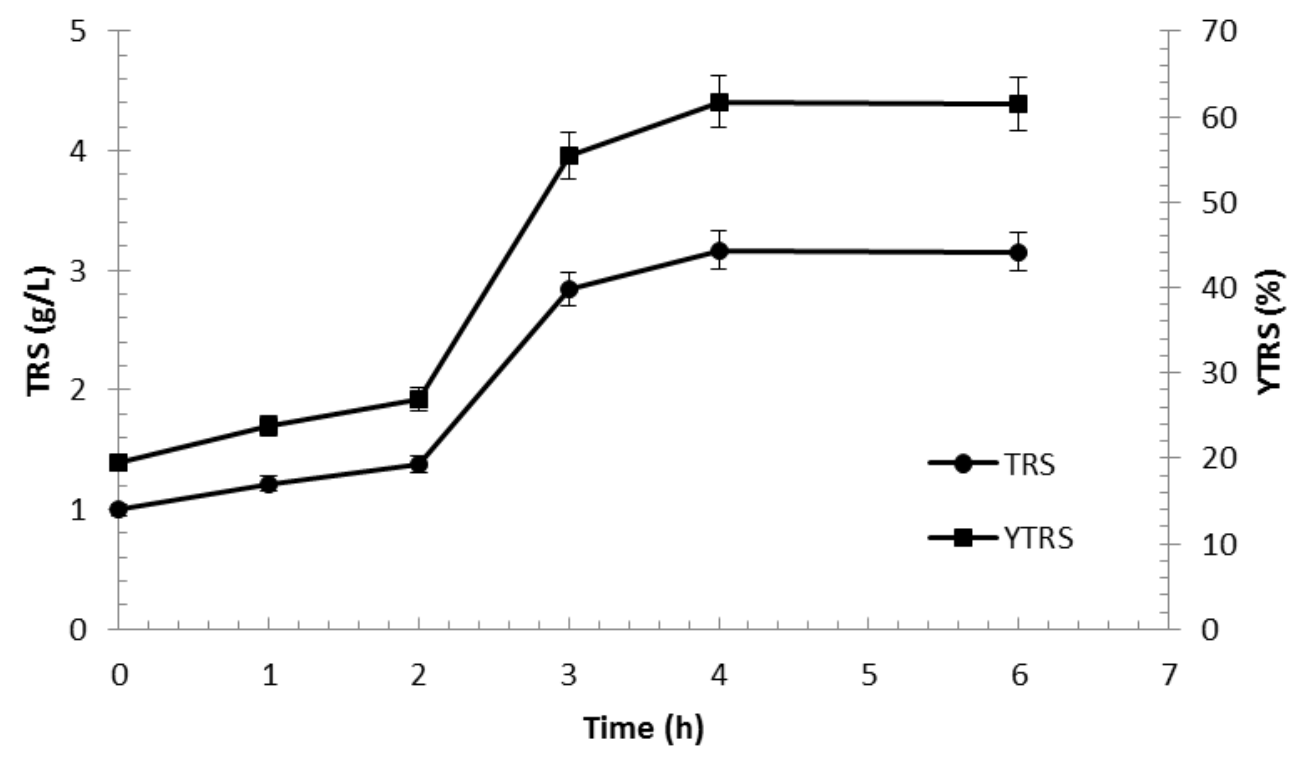

Figure 3: TRS concentration and hydrolysis yield obtained after thermal treatment at $120{ }^{\circ} \mathrm{C}$ and 1 atm for $6 \mathrm{~h}$ and enzymatic (Celluclast ${ }^{\circledR}$ and $\beta$-glucosidase) hydrolysis. The percent TRS yield was calculated by considering that the $K$. alvarezzi total carbohydrate content was $51.3 \%$.

Table 1 summarizes the algae biomass hydrolysis productivity by taking the time employed in the different assays into account. According to the results, the combined treatment (autoclave treatment + enzymatic hydrolysis) reached superior TRS productivity $\left(0.32 \mathrm{~g}\right.$ of TRS/L.h) as compared to Celluclast ${ }^{\circledR}+\beta$ glucosidase treatment, $0.24 \mathrm{~g}$ of TRS/L.h.

Table 1: Hydrolysis yield, TRS concentration, and TRS productivity obtained after the different treatments applied to the $K$. alvarezzi biomass.

\begin{tabular}{ccccc}
\hline TREATMENT & $\begin{array}{c}\mathbf{Y}_{\text {ART }} \\
(\mathbf{\%})\end{array}$ & $\begin{array}{c}\text { TRS IN } \\
\text { HYDROLYSATE } \\
(\mathbf{g} / \mathbf{L})\end{array}$ & $\begin{array}{c}\text { TREATMENT TIME } \\
(\mathbf{h})\end{array}$ & $\begin{array}{c}\text { TRS } \\
\text { PRODUCTIVITY } \\
(\mathbf{g} \text { of TRS/L.h) }\end{array}$ \\
\hline Autoclave & 18.5 & $1.0( \pm 0.1)^{\mathrm{c}}$ & 6 & 0.17 \\
\hline Celluclast ${ }^{\circledR}$ & 31.0 & $1.6( \pm 0.2)^{\mathrm{b}}$ & 12 & 0.13 \\
\hline$\beta$-glucosidase & 4.0 & $0.2( \pm 0.1)^{\mathrm{d}}$ & 8 & 0.02 \\
\hline Celluclast ${ }^{\circledR}+\beta$-glucosidase & 37.0 & $1.9( \pm 0.2)^{\mathrm{b}}$ & 8 & 0.24 \\
\hline Autoclave + enzymatic hydrolysis* & 61.5 & $3.2( \pm 0.2)^{\mathrm{a}}$ & $6+4(10)$ & 0.32 \\
\hline
\end{tabular}


${ }^{*}$ Celluclast ${ }^{\circledR}+\beta$-glucosidase. a, b, c, d : Different small caps in the same column indicate significant difference between different treatments, as revealed by Tukey test, $\mathrm{p}<0.05$.

\subsection{Macroalgae hydrolysate chemical characterization}

The hydrolysis yield was based on the TRS concentration in the hydrolysates only, but oligosaccharide size and fermentation inhibitors can further affect fermentation. Figure 4 illustrates the TLC of the macroalgae hydrolysates as compared to the TLC of standard monosaccharides (Glu - glucose; Gal - galactose) and disaccharide (Cel - cellobiose).

Besides the distinct TRS concentrations in the hydrolysates from autoclave treatment and from enzymatic hydrolysis (Table 1), the carbohydrate polymerization degree was also different. The autoclave treatment (Figure 4- $\mathrm{t}_{0}-\mathrm{t}_{4}$ ) provided hydrolysates containing high-molecular-mass TRS because the carbohydrates remained at the bottom of the TLC plate. On the other hand, enzymatic treatment (Fig 4, lane 1) promoted higher polysaccharide polymerization: TLC revealed the monosaccharides glucose and galactose as well as the disaccharide cellobiose.

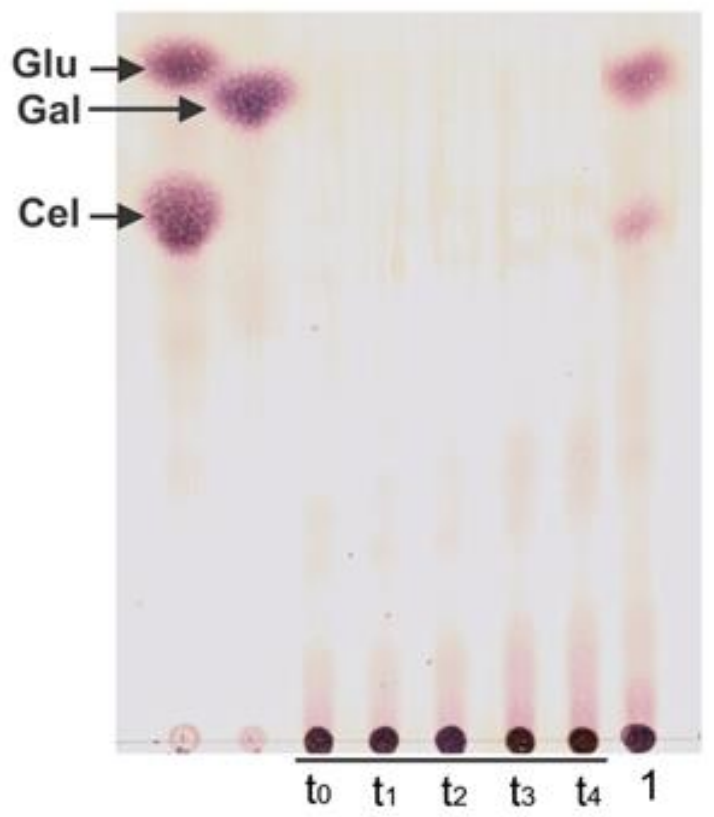

Figure 4: Time-course analysis of macroalgae autoclave treatment: the times were 0 (lanes $\mathrm{t}_{0}$ ), $1 \mathrm{~h}$ (lanes $\mathrm{t}_{1}$ ), $3 \mathrm{~h}$ (lanes $\mathrm{t}_{2}$ ), $4 \mathrm{~h}$ (lanes $\mathrm{t}_{3}$ ), and $6 \mathrm{~h}$ (lanes $\mathrm{t}_{4}$ ), and enzymatic treatment (Celluclast ${ }^{\circledR}+\beta$-glucosidase) (lane 1$)$. Standards: Glu, glucose; Gal, galactose; Cel, cellobiose.

Previous studies have shown that $C$. beijerinckii $\mathrm{Br} 21$ can produce $\mathrm{H}_{2}$ from glucose, galactose, and cellobiose, but not from crystalline cellulose [23]. $\mathrm{H}_{2}$-producing $C$. beijerinckii $\mathrm{Br} 21$ genome contains eleven $\beta$-glucosidase genes (GenBank access no. KT626859). This should aid oligosaccharide fermentation and enable cellobiose fermentation.

Apart from different carbohydrate types, algae biomass hydrolysates may contain significant levels of non-sugar components, such as 5-HMF, a product of hexose degradation that is toxic to microbes used to convert biomass to biofuels $[18,30,31]$. Therefore, it is desirable that hydrolysates contain fermentable sugars but low inhibitor concentration. We analyzed all the samples treated in this study, to detect HMF at 0.1 , $0.5,1.1,1.9,2.8$, and $7.6 \mathrm{mg} / \mathrm{L}$ after autoclave treatment of the sample for $1,2,3,4,5$, and $6 \mathrm{~h}$, respectively. Such concentrations were very low as compared to fermentation inhibitory concentrations described for $\mathrm{H}_{2}$ producing Clostridium in the literature: above $1.0 \mathrm{~g} / \mathrm{L}$ [18, 30, 31]. 


\subsection{Fermentative hydrogen production from macroalgae hydrolysate}

Because the hydrolysate obtained after algae biomass enzymatic hydrolysis presented the highest TRS productivity but no inhibitors, we employed it as substrate for $\mathrm{H}_{2}$ production in fermentative assays. During the fermentative assay, the $\mathrm{H}_{2}$-producing $C$. beijerinckii $\mathrm{Br} 21$ consumed ca. $1 \mathrm{~g} / \mathrm{L}$ TRS from the hydrolysate (5.5 mmol/L, considering TRS as glucose) and produced $11.9 \mathrm{mmol}$ of $\mathrm{H}_{2}$ after $48 \mathrm{~h}$. The yield ( $\left.\mathrm{Y}_{\mathrm{H} 2 / \mathrm{s}}\right)$ was 2 mmol of $\mathrm{H}_{2} / \mathrm{mmol}$ of glucose equivalent and represented $50 \%$ of the stoichiometric yield of $\mathrm{H}_{2}$ production from glucose by Clostridium sp, which is 4 mols of $\mathrm{H}_{2}$ per mol of glucose [1]. The hydrogen yield from algae biomass, $23.8 \mathrm{mmol}$ of $\mathrm{H}_{2} / \mathrm{g}$ of dry algae biomass, was much higher than the yields of between 1.5 and 7.6 mmol of $\mathrm{H}_{2} / \mathrm{g}$ of algae biomass reported in the literature (Table 2).

Table 2: Macroalgae hydrolysate fermentation yield for $\mathrm{H}_{2}$-production by $C$. beijerinckii $\mathrm{Br} 21$ as compared to the literature.

\begin{tabular}{|c|c|c|c|c|}
\hline MACROALGAE & TREATMENT & $\begin{array}{l}\mathrm{H}_{2} \text {-PRODUCING } \\
\text { CULTURE }\end{array}$ & $\begin{array}{c}\mathrm{Y} \\
\text { (mmol of } \mathrm{H}_{2} / \mathrm{g} \\
\text { of dry algae } \\
\text { biomass) }\end{array}$ & REFERENCE \\
\hline K. alvarezzi & Enzymatic & $\begin{array}{c}\text { C. beijerinckii } \\
\mathrm{Br} 21\end{array}$ & 23.8 & This work \\
\hline Saccharinasculpera & Pulverization & Vibrio tritonius & $2.5 * *$ & [32] \\
\hline L. japônica & Thermal $180^{\circ} \mathrm{C} / 40 \mathrm{~min}$. & Anaerobic sludge & 4.4 & [33] \\
\hline L. japônica & $\begin{array}{c}\text { Acid }+ \text { thermal } \\
\left(12 \% \mathrm{HCl}, 140{ }^{\circ} \mathrm{C} / 60\right. \\
\min )\end{array}$ & Anaerobic sludge & 6.7 & [33] \\
\hline G. amansii & $\begin{array}{c}\text { Acid + thermal } \\
\left(1.5 \% \mathrm{H}_{2} \mathrm{SO}_{4}, 180{ }^{\circ} \mathrm{C} / 15\right. \\
\min )\end{array}$ & Anaerobic sludge & 1.5 & [34] \\
\hline $\begin{array}{c}\text { Arthrospiraplatensis }+ \\
\text { Laminaria digitata }\end{array}$ & $\begin{array}{c}\text { Acid + thermal } \\
\left(2.5 \% \mathrm{H}_{2} \mathrm{SO}_{4}, 135{ }^{\circ} \mathrm{C} / 15\right. \\
\text { min })\end{array}$ & Anaerobic sludge & $3.5^{*}$ & [35] \\
\hline G. amansii & $\begin{array}{c}\text { Acid + thermal } \\
\left(1 \% \mathrm{H}_{2} \mathrm{SO}_{4}, 121^{\circ} \mathrm{C} / 30\right. \\
\min )\end{array}$ & Anaerobic sludge & $2.1 * *$ & {$[36]$} \\
\hline
\end{tabular}

*mmol of $\mathrm{H}_{2} / \mathrm{g}$ of volatile solids**Calculated from manuscript data.

Few literature works have addressed the use of macroalgae as substrate for $\mathrm{H}_{2}$ production (see Table 2). Most research on macroalgae as substrate for $\mathrm{H}_{2}$ production has employed acid and thermal treatments for biomass hydrolysis [18]. These treatments could produce much higher inhibitor concentration as compared to enzymatic hydrolysis. In addition, most of the literature works have used mixed cultures such as anaerobic sludges from wastewater treatment plants as $\mathrm{H}_{2}$ producer, but these cultures are not as specific as pure $\mathrm{H}_{2}-$ producing microorganisms. Only one paper has employed a pure Vibrio tritonius culture as biocatalyst, but the yield was 10 times lower than ours [32]. Here, we used a $\mathrm{H}_{2}$-producing Clostridium strain to ferment macroalgae hydrolysate for the first time. We chose to employ the recently isolated C. beijerinckii $\mathrm{Br} 21$ strain because it can produce $\mathrm{H}_{2}$ from galactose as substrate at high conversion ratio $\left(2.02 \mathrm{mmol} \mathrm{of} \mathrm{H}_{2} / \mathrm{mmol}\right.$ of galactose) [23]. Moreover, the Br21 strain can produce hydrolytic enzymes, which could improve pretreated biomass hydrolysis. These $C$. beijerinckii $\mathrm{Br} 21$ strain characteristics help to explain its high performance in $\mathrm{H}_{2}$ production from macroalgae biomass as compared to other works. 


\section{CONCLUSION}

This is the first report that has employed macroalgae biomass ( $K$. alvarezzi) as feedstock for $\mathrm{H}_{2}$ production by a Clostridium strain. Both the autoclave treatment and enzymatic hydrolysis broke down $K$. alvarez$z i$ biomass to a greater or to a lesser degree, to produce hydrolysates with low fermentation inhibitor concentration and available sugars for fermentative $\mathrm{H}_{2}$ production by Clostridium beijerinckii $\mathrm{Br} 21$. Autoclave treatment followed by enzymatic hydrolysis (combined treatment) provided a hydrolysate with higher TRS concentration. Taking the total hydrolysis time into account, the TRS productivity achieved during the combined treatment (thermal treatment + enzymatic hydrolysis) was about $30 \%$ higher than the TRS productivity achieved with enzymatic hydrolysis (Celluclast ${ }^{\circledR}+\beta$ glucosidase). The use of the hydrolysate from enzymatic hydrolysis as feedstock to produce $\mathrm{H}_{2}$ gave high yield as compared to literature data on the use of mixed microorganism cultures to produce $\mathrm{H}_{2}$. In conclusion, both treatments were efficient methods to prepare macroalgae biomass for enhanced bioconversion to $\mathrm{H}_{2}$ by $C$. beijerinckii $\mathrm{Br} 21$.

\section{ACKNOWLEDGMENTS}

This work was supported by FAPESP 2015/06074-1; ELR received a grant from Programa Unificado de Bolsas; BCF received a grant from CAPES; LPM received a post-doctoral scholarship from FAPESP; and SC received a master scholarship from CAPES.

\section{BIBLIOGRAPHY}

[1] DAS, D., VERIZOGLU, T.N., "Hydrogen production by biological processes: a survey of literature", International Journal of Hydrogen Energy, v. 26, n. 1, pp. 13-28, Jan. 2001.

[2] JONES, C.S., MAYFIELD, S.P., "Algae biofuels: versatility for the future of bioenergy", Current Opinion in Biotechnology, v. 23, n. 3, pp. 346-351, Jun. 2012.

[3] MIRANDA, P.E.V., “A energia do hidrogênio”, Matéria (Rio J.), v. 17, n. 1, 2012

[4] CHAUBEY, R., SAHU, S., JAMES, O.O., et al., "A review on development of industrial processes and emerging techniques for production of hydrogen from renewable and sustainable sources", Renewable and Sustainable Energy Reviews, v. 23, pp. 443-462, Jul. 2013.

[5] GALLINA, A.L., MATHEUS, A.P.C., DIAS, B.V., et al., "Aplicação do aço carbono e ferro Armco na produção de gás hidrogênio em ácido fórmico”, Matéria (Rio J.), v. 21, n. 4, p. 880-897, Dez. 2016.

[6] LUO, S., XIAO, B., HU, Z., et al., "Hydrogen-rich gas from catalytic steam gasification of biomass in a fixed bed reactor: Influence of temperature and steam on gasification performance", International Journal of Hydrogen Energy, v. 34, n. 5, pp. 2191-2194, Mar. 2009.

[7] XIA, A., CHENG, J., SONG, W., et al., "Fermentative hydrogen production using algal biomass as feedstock", Renewable and Sustainable Energy Reviews, v. 51, pp. 209-230, Nov. 2015.

[8] YUN, E.J., KIM, H.T., CHO, K.M., et al., "Pretreatment and saccharification of red macroalgae to produce fermentable sugars", Bioresource Technology, v. 199, pp. 311-318, Jan. 2016.

[9] ANDERSSON, V., VIKLUND, S.B., HACKL, R., et al., "Algae-based biofuel production as part of an industrial cluster", Biomass and Bioenergy, v. 71, pp. 113-124, Dec. 2014.

[10] HERNÁNDEZA, D., RIAÑO, B., COCA, M., et al., "Saccharification of carbohydrates in microalgal biomass by physical, chemical and enzymatic pre-treatments as a previous step for bioethanol production", Chemical Engineering Journal, v. 262, pp. 939-945, Feb. 2015.

[11] MAHDY, A., BALLESTEROS, M., GONZÁLEZ-FERNÁNDEZ, C., "Enzymatic pretreatment of chlorella vulgaris for biogas production: influence of urban wastewater as a sole nutrient source on macromolecular profile and biocatalyst efficiency", Bioresource Technology, v. 199, pp. 319-325, Jan. 2016.

[12] PASSOS, F., FERRER, I., "Influence of hydrothermal pretreatment on microalgal biomass anaerobic digestion and bioenergy production”. Water Research, v. 68, pp. 364-373, Jan. 2015. 
[13] PATEL, B., GUO, M., IZADPANAH, A., SHAH, N., et al., "A review on hydrothermal pre-treatment technologies and environmental profiles of algal biomass processing”, Bioresource Technology, v. 199, pp. 288-299, Jan. 2016.

[14] YANG, Z., GUO, R., XU, X., et al., "Fermentative hydrogen production from lipid-extracted microalgal biomass residues", Applied Energy, v. 88, n. 10, pp. 3468-3472, Oct. 2011.

[15] WANG, X., WANG, X., QIN, G., et al., "Comparative study on pyrolysis characteristics and kinetics of lignocellulosic biomass and seaweed", Journal of Thermal Analysis and Calorimetry, v. 132, n. 2, pp. 1317-1323, May. 2018.

[16] XU, Y.P., DUAN, P.G., WANG, F., et al., "Liquid fuel generation from algal biomass via a two-step process: efect of feedstocks", Biotechnology for Biofuels, v. 11, pp. 83, 2018.

[17] ZHU, Z., LIU, Z., ZHANG, Y., et al., "Recovery of reducing sugars and volatile fatty acids from cornstalk at different hydrothermal treatment severity", Bioresource Technology, v. 199, pp. 220-227, Jan. 2016.

[18] MONLAU, F., SAMBUSITI, C., BARAKAT, A., et al., "Do furanic and phenolic compounds of lignocellulosic and algae biomass hydrolyzate inhibit anaerobic mixed cultures? A comprehensive review", Biotechnology Advances, v. 32, n. 5, pp. 934-951, Sep. 2014.

[19] MASARIN, F., CEDENO, F.R., CHAVEZ, E.G., et al., "Chemical analysis and biorefinery of red algae Kappaphycus alvarezii for efficient production of glucose from residue of carrageenan extraction process", Biotechnology for Biofuels, v. 9, pp. 122. Jun. 2016.

[20] SOUZA, F.H.M., MELEIRO, L.P., MACHADO, C.B., et al., "Gene cloning, expression and biochemical characterization of a glucose- and xylose-stimulated B-glucosidase from Humicola insolens RP86", Journal of Molecular Catalysis B: Enzymatic, v. 106, pp. 1-10, Aug. 2014.

[21] DALBELO, G., Utilização de biomassa de alga para a produção de hidrogênio, Dissertação de Msc., FFCLRP/USP, Ribeirão Preto, SP, Brasil, 2017.

[22] GHOSE, T.K., "Measurement of cellulase activities", Pure and Applied Chemistry, v. 59, n. 2, pp. 257268, Jan. 1987.

[23] FONSECA, B.C., GUAZZARONI, M.E., REGINATTO, V., "Fermentative production of $\mathrm{H}_{2}$ from different concentrations of galactose by the new isolate Clostridium beijerinckii Br21", International Journal of Hydrogen Energy, v. 41, n. 46, pp. 21109-21120, Dec. 2016.

[24] MILLER, G.L., "Use of dinitrosalicylic acid reagent for determination of reducing sugar", Analytical Chemistry, v. 31, n. 3, pp. 426-428, Mar. 1959.

[25] CARLI, S., MELEIRO, L.P., ROSA, J.C., et al., "A novel termostable and halotolerant xylanase from Colletotrichum graminicola", Journal of Molecular Catalysis B: Enzymatic, v. 133, n. 1, pp. S508-S517, Nov. 2016.

[26] BARREIRO, D.L., BECK, M., HORNUNG, U., et al., Suitability of hydrothermal liquefaction as a conversion route to produce biofuels from macroalgae”, Algal Research, v. 11, pp. 234-241, Sep. 2015.

[27] ZHANG, Y.H.P., HIMMEL, M.E., MIELENZ, J.R., “Outlook for cellulose improvement: Screening and selection strategies”, Biotechnology Advances, v. 24, n. 5, pp. 452-481. Sep. 2006.

[28] CHAROENSIDDHI, S., LORBEER, A.J., LAHNSTEIN, J., et al., "Enzyme-assisted extraction of carbohydrates from the brown alga Ecklonia radiata: Effect of enzyme type, $\mathrm{pH}$ and buffer on sugar yield and molecular weight profiles", Process Biochemisty. V. 51, n. 10, pp. 1503-1510, Oct. 2016.

[29] LEE, C.H., YUN, E.J., KIM, H.T., et al., "Saccharification of agar using hydrothermal pretreatment and enzymes supplemented with agarolytic $\beta$-galactosidase", Process Biochemistry, v. 50, n. 10, pp. 1629-1633, Oct. 2015.

[30] SIQUEIRA, M.R., REGINATTO, V., "Inhibition of fermentative $\mathrm{H}_{2}$ production by hydrolysis byproducts of lignocellulosic substrates", Renewable Energy, v. 80, pp. 109-116, Aug. 2015. 
[31] WANG, Y., GUO, W., CHEN, B.Y., et al., "Exploring the inhibitory characteristics of acid hydrolysates upon butanol fermentation: a toxicological assessment”, Bioresource Technology, v. 198, pp. 571-576, Dec. 2015.

[32] MATSUMURA, Y., SATO, K., AL-SAARI, N., et al., "Enhanced hydrogen production by a newly described heterotrophic marine bacterium, Vibrio tritonius strain AM2, using seaweed as the feedstock", International Journal of Hydrogen Energy, v. 39, n. 14, pp. 7270-7277, May. 2014.

[33] JUNG, K.W., KIM, D.H., KIM, H.W., et al., "Optimization of combined (acid + thermal) pretreatment for fermentative hydrogen production from Laminaria japonica using response surface methodology (RSM)", International Journal of Hydrogen Energy, v. 36, n. 16, pp. 9626-9631, Aug. 2011.

[34] PARK, J.H., YOON, J.J., PARK, H.D., et al., "Feasibility of biohydrogen production from Gelidiumamansii”, International Journal of Hydrogen Energy, v. 36, n. 21, pp. 13997-14003, Oct. 2011.

[35] XIA, A., JACOB, A., TABASSUM, M.R., et al., "Production of hydrogen, ethanol and volatile fatty acids through co-fermentation of macro- and micro-algae", Bioresource Technology, v. 205, pp. 118-125, Apr. 2016.

[36] SIVAGURUNATHAN, P., KUMAR, G., KOBAYASHI, T., XU, K., KIM, S.H. "Effects of various dilute acid pretreatments on the biochemical hydrogen production potential of marine macroalgal biomass", International Journal of Hydrogen Energy, v. 42, pp. 27600-27606, Nov. 2017.

\section{ORCID}

Emelin Rodrigues Bruna Constante Fonseca Luana Parras Meleiro Sibeli de Carli

Rosa dos Prazeres Melo Furriel Valeria Cress Gelli Valeria Reginatto https://orcid.org/0000-0003-2327-3346

https://orcid.org/0000-0001-9963-5206

https://orcid.org/0000-0001-7104-0358

https://orcid.org/0000-0003-4324-5182

https://orcid.org/0000-0003-3882-362X

https://orcid.org/0000-0002-6500-1763

https://orcid.org/0000-0003-3185-6090 